\title{
THE EXPERIENCE OF EUROPEAN COUNTRIES REGARDING THE EFFECTIVE FUNCTIONING OF LOCAL GOVERNANCE
}

\author{
Andrii M. Blahodarnyi ${ }^{1}$, Olha O. Barabash², Andrii V. Honcharov³, Mykola V. \\ Honcharov ${ }^{4}$, Volodymyr A. Shatilo ${ }^{5}$ \\ Department of General Law Disciplines, National Academy of Security Service of Ukraine, Kyiv, Ukraine ${ }^{1}$; Department of \\ General Law Disciplines, Lviv State University of Internal Affairs, Lviv, Ukraine²; Department of General Law Discipline, \\ Donetsk Law Institute of the Ministry of Internal Affairs of Ukraine, Kryoyi Rih, Ukraine ${ }^{3}$, Department of Theory, History of \\ Law and State and Constitutional Law, University of the State Fiscal Service of Ukraine, Irpin, Ukraine ${ }^{4 ;}$ Department of \\ Constitutional and Administrative Law, Faculty of Economics and Law, National Transport University, Kyiv, Ukraine ${ }^{5}$
}

\begin{abstract}
The experience of European democracies has great significance in building local governance, given its effectiveness, efficiency, and productivity. Local governance touches upon essential civil problems concerning the life of every person in a particular territory. This intensifies the need to search for an optimal model of local governance today. The purpose of the article is to examine the legal regulation of local governance in European countries. The article also aims to clarify the historical aspects of the local government development and comprehensively study the impact of European standards in this area on regional policy. The authors used the scientific method to identify the theoretical basis of the study. An analysis and synthesis were applied for the discussion section to find a common notion and opinion on the study of local government systems. The main method used in the article is the comparison method that allowed us to compare two local government systems and, as a result, find out an optimal one. The same method has been used to determine the factors that influence regional policy. The results obtained are necessary for the further development of local government systems, their improvement, and modernization at the legal and political levels.
\end{abstract}

Keywords: local governance; public authority; public administration; democratization; European Charter of Local Self-Government.

\section{INTRODUCTION}

Local governance is one of the most important parts of public administration. At the same time, it serves as a counterweight to central government. It means, local governance plays a crucial role in the system of checks and balances, preventing the concentration of power at the state level and ultimately predetermining the degree of stability of the state structure. It should be mentioned that local self-governing bodies play an important role of theoretical and practical aspects of the solution of social-economical, cultural, welfare, as well as regional problems. This role is increasing in accordance with the world practice on local governance /1/. Municipal bodies are public governance institutions that are the closest to people, therefore the local level of governance is very favorable for development of public governance $/ 2 /$, /3/.

This means that local governance is the fundamental level of public power, closest to its 
source - the people. The degree of its independence and self-sufficiency determines the nature of the stability of the entire system of public authority as a whole. At the same time, the state legislatively defines the goals, forms, resources, boundaries (territorial and other) of local governance, as evidenced by the Constitution or the law on local governance of any modern state. All powers in the field of local governance are given by the state and are secured by the law that is generally binding. One of the most important international acts on which states are guided in the development of local democracy is European Charter of Local SelfGovernment $/ 4 /$.

It contains fundamental principles and norms, the adherence to which makes it possible to involve wide sections of the population in the management of public affairs. Amidst globalization trends and European integration, local government is developing in a similar direction. Public administration reforms now emphasize principles such as democratization, denationalization, deconcentration, decentralization, subsidiarity, etc. They are formulated by the principles of "good practice" /5/. That is why "the legal system in force and the relationships established within this system with regard to the state central authorities. While on the other hand, it is granted the most stable guarantees of autonomy in exercising its functions" /6/. By improving local governance, it is possible to achieve greater efficiency of public administration as a whole, which meets the interests of the state and society.

At present, the existence of effective local governance that meets international standards is considered as the most important indicator of democracy in the existing state regime. The study of European countries in the field of local governance was carried out through the following steps. First of all, the study analyzed what international legal norms prescribe in relation to local governance. Next, an analysis of legislation in the Continental model of local government and the Anglo-Saxon municipal system was carried out. On the basis of the analyzed material, general conclusions were drawn, as well as prospects and recommendations in the field of local governance were presented.

It should be noted that the research methods were chosen taking into account the aims and objectives set in the article. In order to establish the objectivity and validity of scientific provisions, conclusions and recommendations, we analyze a complex of philosophical, general scientific, and special scientific methods in the article. Methodologically, the authors also implemented a discourse-analytical approach to study this subject. The authors explore the context and language identified in documents related to the local government in European countries and thus contribute to an understanding of how the concept of local government is created in European countries.

This study uses the dialectical method. Thus, in the study, the previously created theoretical knowledge in the field of local governance in European countries was transformed, as well as due to the new theoretical provisions that have been systematically implemented, new modifications to existing knowledge were developed. Also, this study uses the system analysis method that helped to highlight the main features in the field of local governance in European countries.

For example, the formal-logical method was used to define the basic concepts and legal categories related to the analysis of the content and legal regulation of local governance at the international and national levels. In addition, the historical and legal methods were used in the analysis process of the research, as well as in highlighting the main stages of the establishment of local governance in European countries. The method of system analysis made it possible to draw the main conclusions and recommendations for increasing the efficiency of local governance in European countries. 
In turn, we used the comparative method when analyzing the local government in the AngloSaxon municipal system and the Continental model of local government. Based on the analysis of historical experience, scientific works, legislative provisions, we revealed their similarities and differences, and indicated tendencies towards convergence in the field of local government. Also, the logical-legal method was used to clarify the practice with regard to the effective functioning of local government in European countries.

Therefore, the main purpose of the study is to examine the legal regulation of local governance in European countries, to analyze international legal norms prescribe in relation to local governance.

\section{HISTORICAL ASPECTS OF THE EMERGENCE OF THE SELF-GOVERNMENT MODEL}

The history of local governance dates back to ancient times, the Middle Ages, and the present. At the doctrinal level, this question began to become relevant at the end of the eighteenth century, namely, since the bourgeois revolution. Later, industrial development made all the adjustments to the role of local governance. At the present stage, effective local governance is a sign of a democratic society. Nowadays, tasks such as management, supervision, inspection and coordination come to the fore. The role of municipal bodies is increasingly seen in solving the following fundamental tasks: identifying the urgent needs of the population; setting specific priorities; defining the standards of the services provided and finding optimal ways to ensure these standards; cooperation with central and regional authorities in solving tasks of local importance; inspection and coordination of activities of various organizations operating at the local level, cooperation with them (mainly on a contractual basis); lobbying in the interests of local communities; implementation of feedback between service consumers and their direct providers using appropriate democratic mechanisms.
It is also necessary to single out the international acts that had the greatest impact on community development, namely:

- the European Outline Convention on Transfrontier Co-operation between Territorial Communities or Authorities /7/;

- Resolution No. 2 on The European Regional/Spatial Planning Charter (Torremolinos Charter) /8/;

- European Charter of Local Self-Government /9/;

- European Urban Charter /10/;

- The Charter of European Cities \& Towns Towards Sustainability /11/;

- Draft European Charter of Regional Local governance /12/;

- Manifesto for A New Urbanity - European Urban Charter II /13/.

European states regardless of their historical development and traditions of local governance, have been gradually implementing the principles set out in a number of international documents and recommendations, cooperated within various international organizations on this issue, which has generally led to positive results. It should be noted that the largest number of international treaties that regulate the local government issues have been adopted within the Council of Europe, because the effective organization of local governance is one of the most important challenges facing European society today. At the same time, the entry of a country into the Council of Europe means its entry into the Continental legal space and the acceptance by the country of obligations arising from the generally recognized European legal norms.

The norms of the international law, in accordance with the Constitutions of the State parties to international treaties, have become an integral part of the legal system of such states. In turn, local governance in European countries received guarantees not only of an internal nature, but also on an international level. The European Outline Convention on Transfrontier Co-operation between Territorial Communities or Authorities 
/14/ was a natural stage in the development of European regionalism. This was practically the first document that contained the relevant international standards and marked the beginning of the creation of "Euroregions" on the continent - macro-regional integration structures with a developed common socio-economic infrastructure. Establishing the interaction of regions of different countries is aimed not only at improving the welfare of the population, but also improving the system of regional governance and local governance.

Resolution No. 2 on The European Regional/Spatial Planning Charter (Torremolinos Charter) /15/ proclaimed the principles of national and European policies designed to improve the functioning of the member states of the spatial organization of Europe, as well as aimed at solving problems beyond the competence of a particular country. This document proclaims the need for democratic, comprehensive, functional planning and sets the main goals and principles of regional planning: balanced development of regions; improving the quality of life; responsible resource management and environmental protection; rational use of land.

The European Charter of Local Self-Government /16/ defines modern democratic principles for the development of local governance. The Charter is a fundamental international legal document for the member states of the Council of Europe, as it contains standards and principles of organization and implementation of local governance. The purpose of the Charter, inter alia, is to activate the inclusion of residents in the process of selforganization to solve social problems in a particular territory. In addition, the purpose of the European Charter of Local Self-Government /17/ is to compensate for the lack of common European standards for defining and protecting the rights of local authorities. It refers to local governance as a government as close as possible to citizens. Education, health care, housing and communal services, public transport, consumer services and many other issues are of concern to every inhabitant of the country. The parties to the Charter undertake to legislate and apply in practice legal norms that guarantee the political, administrative and financial independence of local authorities.

The European Urban Charter /18/ defines the rights of citizens living in European cities. It is a practical guide to urban governance, addressing issues such as living conditions, urban architecture, urban transport, energy, sports and leisure, urban pollution, and street safety. The Charter of European Cities \& Towns Towards Sustainability /19/ was approved by the parties to the European Convention on the Sustainable Development of Large and Small Cities of Europe in Aalborg, Denmark in 1994. The Charter obliges representatives of European cities and towns to begin the process of preparing a local 21st Century Agenda and to develop long-term action plans for the transition to sustainable development.

The European Charter of Regional SelfGovernment, 1997 focuses on the principle of subsidiarity and has begun to work on supplementing the European Charter of Local Self-Government $/ \mathbf{2 0} /$ and the relevant legal instrument for the protection and guarantee of the rights of the local and regional governance institution /21/. On 29 May 2008, the renewed and updated Manifesto for a New Urbanity /22/ was adopted as an annex to Resolution 269 during the 15th plenary session of the Congress of Local and Regional Authorities of the Council of Europe in 2008. The Charter has become a kind of ambitious and demanding message from the Council of Europe to all parties (urban territorial communities, their inhabitants, representative and executive bodies of local governance, their officials) interested in urban development. It should be noted that international legal norms in the field of local governance should become the foundation for building a unique system of effective and capable local governance, as it is on their basis that the most developed local governance systems in the world operate. 
III. COMPARATIVE CHARACTERISTICS OF

THE UNDERLYING MODELS

The definition of decentralization can also be found in official sources (Table 1):

Table 1. Definitions of decentralization compared

\begin{tabular}{|l|l|}
\hline Agencies & Core definition of 'decentralization' \\
\hline World Bank & $\begin{array}{l}\text { Decentralization is the transfer of authority and responsibility for public } \\
\text { functions from the central government to intermediate and local } \\
\text { governments or quasi-independent government organizations and/or } \\
\text { the private sector. It is a complex multifaceted concept. Different types } \\
\text { of decentralization should be distinguished because they have different } \\
\text { characteristics, policy implications and conditions for success. Types of } \\
\text { decentralization include political, administrative, fiscal and market } \\
\text { decentralization. }\end{array}$ \\
\hline $\begin{array}{l}\text { UNDP } \begin{array}{l}\text { Decentralized Governance } \\
\text { for } \\
\text { Development: } \\
\text { A Combined Practice Note } \\
\text { on } \\
\text { Decentralization, } \\
\text { Governance } \\
\text { and } \\
\text { Development }\end{array} \\
\text { central, regional and local levels according to the principle of } \\
\text { subsidiarity. Based on this principle, functions (or tasks) are transferred } \\
\text { to the lowest institutional or social level that is capable (or potentially } \\
\text { capable) of completing them. } \\
\text { French Cooperation } \\
\text { on } \\
\text { local governance } \\
\text { and sub-national institutions, whether they are public, private, or civic. } \\
\text { There are four main types of decentralization: political, fiscal, } \\
\text { administrative and divestment. }\end{array}$ \\
\hline $\begin{array}{l}\text { Decentralization is part of democratic governance. It is intended to give } \\
\text { local authorities their own resources and responsibilities separate from } \\
\text { those of central government, to have their authorities elected by local } \\
\text { communities and to ensure a better balance of power throughout the } \\
\text { territory. } \\
\text { Decentralization brings the decision-making process closer to citizens, } \\
\text { encouraging the emergence of local-level democracy. It aims to achieve } \\
\text { socio-economic development in sectors that often suffer from over- } \\
\text { centralized decision-making. It encourages territorial cohesion and the } \\
\text { anchoring of democracy. It also contributes to fighting poverty }\end{array}$ \\
\hline
\end{tabular}

The historical prerequisite for the formation of decentralized power in most European states was the inability of the central government (in the person of monarchs, emperors, kings, etc.) to ensure effective management of all regions of their state $/ 23 /$. The monarchs were forced to abandon the concentration of all power in their hands and create decentralized authorities on the ground. During management, they applied administrative decentralization of power in the form of deconcentration of power and delegation of powers to a lower administrative-territorial level. That is, already at the end of the $5^{\text {th }}$ century, Western European countries were characterized by certain signs of the power decentralization (delegation of broad powers to local authorities in the Carolingian Empire, the functioning of people's bodies in the Scandinavian states) /24/.

We would like to note that the development of decentralization of local government in the EU countries was also influenced by the formation of various legal systems. Thus, during the municipal 
reforms, three main models of local government were identified (Table 2):

Table 2. Main models of local government in European countries

\begin{tabular}{|c|c|c|}
\hline $\begin{array}{l}\text { Model of local } \\
\text { government }\end{array}$ & $\begin{array}{c}\text { Countries that use } \\
\text { this model of local } \\
\text { government }\end{array}$ & General features \\
\hline Anglo-Saxon & - Great Britain & $\begin{array}{l}\text { - High level of autonomy of local self-government, election and } \\
\text { control by the population. } \\
\text { - Absence of special state commissioners on the ground who are } \\
\text { entrusted with the function of control over local self-government } \\
\text { bodies. } \\
\text { - Lack of local administrations (local authorities). }\end{array}$ \\
\hline $\begin{array}{l}\text { Continental } \\
\text { (French) }\end{array}$ & $\begin{array}{l}\text { - France } \\
\text { - Italy } \\
\text { - Spain } \\
\text { - Belgium } \\
\text { - The Netherlands } \\
\text { - Poland } \\
\text { - Bulgaria }\end{array}$ & $\begin{array}{l}\text { - Combination of direct public administration and local self- } \\
\text { government. } \\
\text { - A certain hierarchy of the management system in which local } \\
\text { self-government is a link in comparison with state power. } \\
\text { - Limited autonomy of local self-government, availability of } \\
\text { special state commissioners on the ground who control local } \\
\text { self-government bodies. }\end{array}$ \\
\hline Mixed & $\begin{array}{l}\text { - Germany } \\
\text { - Austria }\end{array}$ & $\begin{array}{l}\text {-In some levels of local self-government, an elected body can be } \\
\text { both a link of municipal government and a representative of the } \\
\text { state administration. }\end{array}$ \\
\hline
\end{tabular}

However, despite the existence of various models of local self-government and the presence of national characteristics in the distribution of powers between local and central authorities, there are common features that characterize the decentralization processes in European countries: "high quality of public administration and legislation; accountability of state authorities and taking into account the opinion of the population; political stability; lack of violence; high level of government efficiency; curbing corruption" /25/.

Also, the consequence of such reforms was the expansion of the competence of regional and local authorities, that is, the decentralization of management, as well as the consolidation of administrative-territorial units (Sweden, Belgium, Germany, Denmark, Poland). In many countries of the European Union, the Continental (French) system of local government had spread. This system is based on a combination of public administration and local government /26/.
Regarding this context, it would be advisable to consider the experience of France. According to the current French Constitution of 1958, the local self-government system in this country consists of 5 levels (from bottom to top):

- commune;

- canton;

- district;

- department;

- region (les collectivités de droit commun), as well as collectives with a special status (les collectivités à statut particulier).

Each commune has the right to elect a mayor and a municipal council, which have the same scope of authority regardless of the quantitative / territorial characteristics of the commune. Since 1982 the communes have been granted a special status and the possibility of division into municipal districts (municipal arrondissements), such as Paris, Lyon, and Marseille. The document 
regulating in detail the activities of the communes is the Code of Collective Territorial Units "Code général des collectivités territoriales" /27/. However, this does not mean that communes can do whatever they like, as there are the following important restrictions.

For example, the mayor, not the council, is responsible for public order. Most of the important administrative decisions in the municipality (especially the annual budget) must be approved by the authorities of the department, and in some cases by the Regional Court of Accounts. In some cases, (the creation of a semiprivate company, the shareholder of which will be the commune), the consent of the administrative sections of the State Council is necessary /28/. Despite the reforms, the control system remains detailed and important. Also decisions of mayors, municipalities, regions, departments, and regional councils, as well as prefects may be canceled or changed in the local courts of administrative justice and the Council of State. French local governments, especially communes, are seen as part of the administrative bodies and are subject to be controlled by higher structures.

The powers of local government bodies in the UK are governed by both general regulations and private acts of parliament. The most important powers of local authorities include issues such as maintaining public order and security, organizing preschool and school education, including the maintenance of school buildings, kindergartens, specialized institutions for children with disabilities, territorial planning, land use management, fire protection, water supply, sewerage, wastewater discharge, utilization of municipal waste, environmental pollution control, health care, operation of sanitary facilities, provision of the population with electricity, gas and heat, lighting and street cleaning, traffic regulation, maintenance of roads, communal cemeteries, organization of funeral services, development of trade and markets, etc. /29/.
The features of this system are:

- the absence of plenipotentiary representatives of the government on the ground, exercising control over the legality of the actions of local elected bodies; independent decisions by municipal bodies within the law that are not within the competence of central state bodies;

- considering municipalities as autonomous entities exercising power vested in them by parliament;

- along with representative bodies in countries with such a system of local government, a number of officials are elected directly by the population; the control exercised over the activities of local authorities is of an indirect nature - mainly through central ministries;

- the status of local governments is based on general principles, unified, but may vary depending on local conditions;

- the election of local authorities is a democratic and tradition-sanctified way of exercising unified government, directed from the center;

- all public administration is aimed at realizing the national interest; residents of territorial entities are connected only by neighborhood;

- they do not form a special community.

Comparing the Anglo-Saxon and the Continental models of local governance, one can come to the conclusion that in most democratic states the line between these ones fundamentally different municipal systems is erased, which indicates the fact of the formation of a certain unified, decentralized, (hybrid) model. Thus, today we can say that, in general, European systems of local governance have the following attributes: the status of local authorities is enshrined in national constitutions, which provide guarantees of their powers; a very wide range of functions of local authorities; the integration of local authorities into national government structures, interdependence and mutual understanding 
between different levels of social governance; the possibility of political influence of local authorities on state bodies through their associations and other integrative institutions of local government.

\section{CURRENT EXAMPLES OF SELF- GOVERNMENT MODELS IN EUROPEAN COUNTRIES}

Thus, in European countries in recent decades there have been processes of strengthening subnational levels of government but according to different schemes. It is advisable to pay attention to the measures taken in many countries to consolidate territorial communities. In particular, the path of unification and strengthening of the local level of government has been taken by northern European and some postsocialist Central and Eastern European countries. This applies primarily unitary countries. Since 1950, the total number of local governments in Europe has decreased significantly by almost 40,000 due to urbanization processes and the focus on improving the efficiency of public services (benefits) at the local level.

For example, in Denmark, the system of local selfgovernment has been further strengthened by consolidating territorial communities and securing reliable sources of income for them since 2007. In particular, the number of communes decreased from 271 to 98 , and their size increased significantly - almost $75 \%$ of communities with a population of over 30,000 , and the average number exceeds 50,000 people. In addition, enlargement affected regions from 14 to 5 with a population of 0.6-1.6 million, which allowed them to join the NUTS-2 group of regions and thus become objects of the EU regional policy (EU cohesion policy). In fact, the main level of government is local, which provides a wide range of functions - from local economic to social: primary education, special education for adults, care for the elderly, security health, local road management, etc. /30/.

Nevertheless, a significant number of services are provided at the local level through inter- municipal cooperation mechanisms in Finland. For example, now there are general medical centers to serve a number of small municipalities, and a specialized medicine encompasses medical districts administered by joint municipal councils. In addition, cooperation is carried out in the areas of education, waste disposal, water supply, or the like. The main source of revenue for municipal budgets is also income tax while property tax is only $3 \%$. The share of transfers is $18 \%$, and municipalities have a fairly high level of autonomy in decision-making on their expenditure within the limits allowed by national standards and regulations /31/.

For countries that have not followed the path of consolidation at the local level, the mechanisms of inter-municipal cooperation have become the only opportunity to provide a wide range of services on the ground. The practice of intermunicipal cooperation is most developed in France where the number of inter-municipal units exceeds 2,500, and about $93 \%$ of all communes are involved in their activities. Cooperation can be implemented as an easy form - without proper funding, achieving solely for the purpose of ensuring the provision of certain joint services, and in the form of creating an inter-municipal unit with its own funding to perform the powers delegated by the founding municipalities /32/. Of course, such a system of providing the population with the necessary public services on the ground is much more complex than through the simple consolidation of communities, but it is more in line with the essence of decentralization in terms of laying and implementation of local government responsibilities on the ground.

From the point of view of the distribution of financial resources, France is one of the most centralized countries in the EU, and through all subnational levels (regions, departments and municipalities) only about $20 \%$ of all public expenditures are made and distributed about $11 \%$ of tax revenues. Approximately $50 \%$ of local revenues are generated by their own taxes, which are of four types: 
- property taxes (housing, land) $-51.7 \%$ of tax revenues;

- business taxes - 32.5\%; taxation of certain goods and services $-12.7 \%$;

- taxes on the use of specific goods (excises) $2.9 \%$.

The government determines the range in which the rates of each of the four basic taxes can be reduced, distributed between different levels of government $/ 33 /$. The modern practice of the EU member states provides for the possibility of introducing other models of decentralization without strengthening the local level. In particular, Spain is an example of the so-called regional decentralization when the main results of decentralization are concentrated in the direction of the transfer of powers from the central government to the governments of the autonomies (regions).

It should also be noted that in the EU, regions (including municipalities or communes) are subject not only to state or regional policy, but also to an extremely strong EU cohesion policy, which accounts for a third of the Community budget. In fact, within each country, the issue of distribution of powers and management resources can be decided by different decentralized or centralized models. However, large-scale processes of centralized redistribution of budgets are being implemented at the EU level resources for regional policy purposes. In most cases, the beneficiaries are the least developed regions. In fact, regional authorities in the EU member states, in addition to their own resources, have access to a large amount of the shared EU resources. In particular, it is unlikely that decentralization reforms in Poland would be so successful without successfully attracting and using the largest amount of resources allocated from the EU budget for cohesion policy. Thus, Polish communities and regions have had the opportunity to use large amounts of resources for development, and since 2011, have become leaders in the amount allocated from the EU budget $/ \mathbf{3 4} /$.
At this stage in Poland, an important task of local governments is to equalize the living standards of urban and rural residents. A special agricultural development program (SAPARD2001-2004) has been created for this purpose. For the development of urban infrastructure 4,493 contracts worth more than 2,024 million zlotys (500 million euros) were concluded in the area. 2139 contracts were concluded for the repair of municipal roads, 1303 contracts - for the treatment of municipal wastewater, 987 contracts - for the supply water to agriculture, 39 contracts - for energy supply, 25 - waste management /35/.

This testifies to the main role of local governments in resolving issues of local importance. The SAPARD program has played an important educational role, in particular on how beneficiaries can access the EU funds. Procedures for filling out documents and implementing investments and monitoring their use were worked out. The mechanisms of financial fees have been introduced, and the SAPARD Fund Management Agency, the Agency for Development and Modernization, has been established. As a result of the changes, local authorities have gained access to the EU funds from the European Regional Development Fund, the European Social Fund, the European Agricultural Management and Guarantee Fund, the Financial Instrument for Fisheries Management, the Cohesion Fund (targeting Member States whose gross national income per capita is less than $90 \%$ of the EU average, aimed at reducing economic and social inequality and promoting sustainable development).

It should be noted that decentralization of management is not a panacea and a guarantee of rapid improvement in the quality of life. So, to decide whether to support or reject the decentralization, all its advantages and disadvantages should be taken into account (Table 3). 
Table 3. Two perspectives on decentralization

\begin{tabular}{|c|c|}
\hline Pro & Contra \\
\hline $\begin{array}{l}\text { - "elections are fair and free and a local } \\
\text { competitive political system will emerge" }\end{array}$ & $\begin{array}{l}\text { - "the governance conditions are such that we will } \\
\text { only create another layer of state inefficiency" }\end{array}$ \\
\hline $\begin{array}{l}\text { - "resources will be made available from the } \\
\text { central state or from local taxation" }\end{array}$ & $\begin{array}{l}\text { - "decentralization is too costly a process } \\
\text { (including a risk of fiscal indiscipline), so most } \\
\text { countries (especially small ones) cannot } \\
\text { afford it" }\end{array}$ \\
\hline $\begin{array}{l}\text { - "decision-making on local plans and priorities } \\
\text { will take place at local level, not at the center" }\end{array}$ & $\begin{array}{l}\text { "n should not take place before } \\
\text { city exists at central level" }\end{array}$ \\
\hline $\begin{array}{l}\text { - "the new democratic system at local level will be } \\
\text { able to cope } \\
\text { with alternative (traditional) sources of authority" }\end{array}$ & $\begin{array}{l}\text { - "decentralization has uncertain impact on } \\
\text { poverty reduction" }\end{array}$ \\
\hline $\begin{array}{l}\text { - "decentralizing service delivery leads to better } \\
\text { results that benefit poor people" }\end{array}$ & $\begin{array}{l}\text { - "th } \\
\text { prom }\end{array}$ \\
\hline $\begin{array}{l}\text { - "citizens will be able to exercise voice in the } \\
\text { management of local affairs" }\end{array}$ & $\begin{array}{l}\text { - "decentralization will lead to a clash between } \\
\text { different sources of power and legitimacies" }\end{array}$ \\
\hline
\end{tabular}

\section{SCIENTIFIC VIEW ON THE PROBLEMS OF LOCAL SELF-GOVERNMENT DEVELOPMENT}

The complex multifunctional nature of local governance as a territorial organization of public authority determines the constant interest of representatives of various sciences. In recent years, considerable attention has been paid to the scientific study of the problems of local governance and local development. Thus, among the scholars who have studied various aspects of the development of local governance, we should highlight the works of Yu. Shemshuchenko /36/, K. Ismayilov /37/, V. Kiurienř /38/, R. Kamiński /39/, A. Blanusa/40/, E. Pal /41/, N. Muminov /42/, and others. For example, R. Kamiński /43/ mentioned that local governance as one of the segments of the public administration system is an element of public authority exercised by a selfgoverning commune itself or by the institutions established for broadly defined public benefits. It should be affirmed that there is no local government autonomy that could be complete and absolute. If such solutions were to exist, it could threaten unity of the state, while, on the other hand, it would imply that there would be no dependence on anybody, at whatever time and in whatever manner $/ \mathbf{4 4 / .}$

The Legal Encyclopedia edited by Yu.S. Shemshuchenko /45/ establishes that local governance is a political and legal institution of public power by which local affairs are managed within administrative-territorial units through self-organization of the residents of a certain territory with support from the state. In science, the following features of local governance are distinguished: it is a separate municipal community endowed with a special legal status that allows to decide its own affairs; the structure of self-governing communities is based on local governance, which allows territorial communities to decide the affairs of their residents independently of public authorities; local governance of territorial communities is not absolute - they can act only within the legally defined limits $/ 46 /$.

A. Blanusa /47/ studied the importance of local governance and citizen participation in modern society. In this regard, she emphasized that it is necessary to find constitutional and legal solutions for smooth decision-making in local 
government, for the common benefit of all who live in the local community. The justification of this research is mostly reflected in the fact that the permanent participation of citizens in decisionmaking increases efficiency and democracy in the work of local governments. E. Pal /48/ researched the models of legal supervision over local selfgovernments in Continental Europe. The researcher mentioned that the state control over the activities and decisions of local governance means legal supervision that differs in intensity because of the wide range of the competences supervisory authorities are provided with. In general, supervisor expediency has been drastically reduced, yet it is still present with regard to certain types of decisions in Belgium, Germany, Austria, Poland and Slovenia.

At the same time, O. Petryshyn /49/ mentioned that reforming local governance in accordance with the norms of international law is a whole set of actions that includes: any form of implementation of international norms into the domestic legislation of the state; providing financial, material and organizational bases for the implementation of such norms; creation of simplified mechanisms for further improvement and self-development of the local governance system in accordance with international standards; ensuring compliance with the provisions of the implemented international norms by consolidating the responsibility of bodies and officials of local governance for violating the general principles of international law and its norms.

Local governance occupies a leading place in the processes of globalization, international interstate integration and the formation of modern constitutional law. Capable local governance is considered as one of those attributes of modern constitutionalism and social-legal democratic statehood that, in the context of the European vector of development, requires its comprehensive principles of institutionalization, human dimension of public power and the rule of law /50/. Taking into account all of the above, it should be pointed out that international agreements are important sources in the field of local governance, since they contribute to its formation and approval of modern development trends. It is noteworthy that international standards of local governance are a certain foundation for the development of the local governance autonomy and adjust the interaction of a state and municipal authorities towards the realization of the right to local self-government.

The development of local governance is one of the priorities of state policy. In the last few decades, one of the main trends in the development of local government is the reform of the territorial organization of power on the basis of the decentralization and subsidiarity principles. In general, decentralization means a way of defining and delimiting tasks and functions in which most of them are transferred from the level of central bodies to a lower level, and become the own tasks and powers of the level bodies that are the closest to local residents /51/. So, decentralization is a rather complex concept that can be disclosed through its influence on the administrativeterritorial structure of the state, the system of public administration bodies, the distribution of functions, powers and financial resources between them.

In turn, $\mathrm{V}$. Bordenyuk /52/ notes that the system of relations between local self-government bodies and public authorities is associated with deconcentration and decentralization. According to the author, the effectiveness of the functioning of the local government system is influenced by the relationship between decentralization and deconcentration of power, the ratio of functions and competence of government bodies, their distribution according to functional and sectoral principles. K. Mizsei /53/ argues that decentralization is needed to more even economic growth and income redistribution. Local governments should implement their own projects. They need their own base for this, the ability to transparently protect its share of the central taxes and a certain autonomy in the use of part of the collected taxes. 
The reform of strengthening the municipal level was also carried out in Finland through voluntary associations (the number of municipalities decreased from 450 to 320 ), and compared to other northern countries, Finnish municipalities became larger than Icelandic and Norwegian, but less numerous than Danish (the average number is more than 50,000) and Swedish $(30,000)$. In general, the average size of municipalities is about 17,000 inhabitants, but there are also a significant number of communities (almost half) with a population of less than 6,000 people. In the presence of such relatively small communities, it was impossible for them to perform a wide range of functions on their own.

Local self-government is an indispensable attribute of any modern democratic society. Foreign municipalism knows a variety of models for organizing local self-government. Differences in the construction of local self-government systems depend on many factors: the dominant idea of organizing power and governance in the country on the local level, the state structure and administrative-territorial division of the state, national traditions, etc. At the same time, at present, in the scientific literature, the division of the local self-government models into the Continental and the Anglo-Saxon models is most common. The local government capacities and local government performance in Europe clearly make this continent one of the most developed world areas from the point of view of local democracy. The background factors explaining this situation have a multidimensional character, and one can identify the relative economic wealth, high human development, the long historical tradition of the subsidiarity principle in most parts of Europe, and the regulatory function of the Council of Europe as core positive factors $/ 54 /$.

At the same time, S. Ukovic and M. Hacek /55/ distinguish two different regimes or models of local authorities that differ in size, structure, tasks, and relationships with the state. However, a common feature is the emergence from their own traditions and historical development. It is expected that different models of local selfauthorities will also be preserved in the future, as there cannot exist only a single model either within individual federal states, let alone at the pan-European level. Agreeing with the authors, it should be noted that thanks to the development of the European Union and pan-European integration, pan-European norms have an impact on the competence of the municipalities in the EU member states. It should be pointed out that in the Lisbon Treaty, which entered into force on December 1, 2009, the EU for the first time in European law enshrined in the protocol to this treaty a fairly "wide discretion" of municipalities in decision-making.

For example, N. Shpotyuk/56/ mentioned that the differences between the Continental system of local government and the Anglo-Saxon one in Europe are fundamental, as they are based on different concepts of local government and its role in the public law system. However, the European bureaucracy, which has appropriated a significant amount of power over the management of European affairs, transferred to it by all the EU member states that have ceded certain signs of state sovereignty, is influencing the convergence of these legal systems. This manifested itself in the course of municipal reforms in France and Great Britain in the 1980s and the evolution of the local government system in a number of federal states of Germany. Therefore, the foundations of the functioning of both macrosystems of local government in the EU are based on the same principles characteristic of the modern state. First of all, it is said that local representative bodies of the countries of the European space are formed by the population as a result of free and competitive elections and therefore have considerable legitimacy /57/.

At the same time, it should be noted that however the United Kingdom of Great Britain and Northern Ireland is not any more a part of the EU we cannot deny the fact of the previous influence of the EU supranational norms in the field of local self-government on this country, which is a prominent example of the Anglo-Saxon model of 
local self-government in Europe. Moreover, some authors even mention that, comparing the Continental and the Anglo-Saxon models of local self-government, it should be borne in mind that in democratically developed countries the differences between these two models are not fundamental. Their modern form, which is largely the result of the local self-government reforms, allows to distinguish certain convergence of the once very different municipal systems /58, 59/. However, in our research, we distinguish common and different features of the Continental and the Anglo-Saxon models of local self-government. In spite of the fact that it was an influence of the EU law on the Anglo-Saxon model of local government, it is early to talk about convergence of the Continental and the AngloSaxon models of local government.

\section{CONCLUSIONS}

Foreign experience of organizing municipal institutions shows that local governance and public administration are combined, taking into account the historical, demographic, geographical characteristics of a particular country, forms of government, political regime, legal system and other factors. The formation of local governance in European countries took place over a long historical period. This process continues today. This is primarily due to the fact that, although the Western European bodies of state power and local governance are predominantly stable and effective, the governments of these countries are constantly making efforts to improve them. In most countries of the world, local government is the most important part of public administration. It plays the role of a counterweight to central government, is characterized by a certain degree of independence, determines the degree of decentralization of state power and shows the state of development of democratic principles in society.

The powers of local authorities, as a rule, are enshrined in special regulations. A number of foreign constitutions contain either chapters or individual articles devoted to local governance.
Typically, such chapters are short in length and contain references to current legislation. The constitutions of European states enshrine such principles of local governance as decentralization, representative democracy, autonomy, subsidiarity, and freedom of association. The analysis of the provisions of the above-mentioned international agreements shows a movement towards a certain unification and standardization of the principles of organization and implementation of local governance in European countries.

In foreign countries, there are various types of local governance that predetermines the development of national municipal legislation. In the modern world, there are two main models of the local government system: Anglo-Saxon and Continental. In our research, we distinguish common and different features of these two systems.

The research demonstrated, that the main criteria for identifying the differences between the AngloSaxon and the Continental models of the implementation of municipal power are the degree of the local authority autonomy and the nature of the empowerment. However, there are also common features in these two models that was influenced by the EU supranational norms that, inter alia, affected the United Kingdom of Great Britain and Northern Ireland, which was a part of European Union till 2020.

At the same time, a comparative analysis of the main patterns of the development of local selfgovernment in the Continental and the AngloSaxon models reveals the specifics of the management mechanism, its content, the number of assigned duties, and also provides for drawing up possible schemes for organizing local selfgovernment. Further research will be useful to summarize the experience of local authorities.

As a continuation of this work, it seems reasonable to use statistical methods of analysis carried out in the EU countries in the sphere of the development of participation and trust in the 
local self-government system. In particular, regulatory impact assessment techniques can play an important role. In combination with theoretical analysis, empirical and practiceoriented methods will make it possible to develop recommendations regarding the selection of the optimal model of local self-government and development of the country.

Notes

/1/ Ismayilov, K. (2018), The formation and evolution of local governance in Azerbaijan and modern local governance in the Post-Soviet countries (issues of legal regulation). Journal of Legal, Ethical and Regulatory Issues, 3, 1-14

/2/ Kiurienř, V. (2015), Administrative supervision of local governance in the Baltic states: A comparative view. Journal of Education Culture and Society, 2, 394410 .

/3/ Barabash, O. (2017), Peculiarities of IT-education in Ukraine. In Proceedings of the 12th International Scientific and Technical Conference on Computer Sciences and Information Technologies, CSIT 2017, Vol. 1 (Ukraine, September 2017) (pp. 313-317). Lviv: Institute of Electrical and Electronics Engineers.

/4/ European Charter of Local Self-Government. (1985), Retrieved from https://rm.coe.int/168007a088.

/5/ Bakoš, E., Soukopová, J., \& Selešovský J. (2015), The historical roots of local governance in Czech and Slovak Republics. Lex Localis. Journal of Local Governance, 1, 1-19.

/6/ Kamiński, R. (2018), The autonomy of local governance units - legal and financial aspects. Central and Eastern European Journal of Management and Economics, 3, 51-66

/7/ The European Outline Convention on Transfrontier Co-operation between Territorial Communities or Authorities. (1980), Retrieved from https://www.coe.int/en/web/conventions/full-list//conventions/treaty/106.

/8/ Resolution No. 2 on The European regional/spatial planning charter (Torremolinos Charter). (1983), Retrieved from https://rm.coe.int/6th-europeanconference-of-ministers-responsible-for-regionalplanning/16807

/9/ op. sit. in /4/

/10/ European Urban Charter. (1992), Retrieved from https://rm.coe.int/168071923d.
/11/ The Charter of European Cities \& Towns Towards Sustainability. (1994), Retrieved from http://portal.uur.cz/pdf/aalborg-charter-1994.pdf

/12/ Draft European Charter of Regional Local Governance. (1997), Retrived from https://www.cvce.eu/en/obj/draft_european_cha rter_of_regional_self_government_5_june_1997en-78ae4dcf-6346-4aa8-8474-7535e4091bf7.html.

/13/ Manifesto for a New Urbanity. (2008), European Urban Charter II. Retrieved from https://rm.coe.int/urban-charter-ii-manifesto-fora-new-urbanity-publication-a5-58-pages/168095e1d5

/14/ op. sit. in /7/

/15/ op. sit. in /8/

/16/ op. sit. in /4/

/17/ op. sit. in /4/

/18/ op. sit. in /10/

/19/ op. sit. in /11/

/20/ op. sit. in /4/

/21/ op. sit. in /12/

/22/ op. sit. in /13/

/23/ Konte, M., \& Vincent, R. C. (2021), Mining and quality of public services: The role of local governance and decentralization. World Development, $140 . \quad$ DOI: 10.1016/j.worlddev.2020.105350

/24/ Ayhan, F. (2020), Local governance and regional development: current perspectives. Berlin: Peter Lang.

/25/ The Social Progress Imperative. (2018), World rankings for social progress 2018/Humanitarian Technology Centre. Retrieved from: http://gtmarket.ru/news/2014/04/14/6688.

/26/ Muminov, N., Alidjanova, Oz., Mardonov, K., \& Rakhimov, G. (2020), Models of the development of local governance and the experience of decentralization: an institutional approach. International Journal of Psychosocial Rehabilitation, 4, 1954-1964.

/27/ Code of Collective Territorial Units "Code général des collectivités territoriales". (1996), Supportting Decentralization and Local Governannce in third Countrries. Retrieved from: https://eeas.europa.eu/archives/delegations/swazil and/documents/eu_swaziland/supporting_decentr alisation_and_local_governance_in_third_countrie s_january_2007.pdf

/28/ Nguyen, B. (2021), Regional informal institutions, local governance and gendered entrepreneurship. Regional Studies, 55(7), 1169-1181.

/29/ Kostyuchenko, O.E., Kolesnik, T.V., Bilous, Z.V., \& Tavolzhanskyi, O.V. (2019), Robotization of 
manufacturing process: economic and social problems and legal ways of their solution. Financial and Credit Activity: Problems of Theory and Practice, 3(30), 454-462.

/30/ Vapniarchuk, V.V., Puchkovska, I.I., Tavolzhanskyi, O.V., \& Tashian, R.I. (2019), Protection of ownership right in the court: the essence and particularities. Asia Life Science, 21(2), $1-19$.

/31/ op. sit. in /15/

/32/ Palacios Garay, J. P., Toledo-Córdova, M. F., Miranda-Aburto, E. J., \& Flores Farro, A. (2021), Public policies and local participatory governance. Revista Venezolana De Gerencia, 26(95), 564-577.

/33/ Committee of the Regions of the EU. (2012), Study on the Division of Powers between the European Union, the Member States, and Regional and Local Authorities., Retrieved from https:/cor.europa.eu/en/engage/studies/Docume nts/division_of_powers/division_of_powers.pdf

/34/ Samilyk, L.O., Maliarova, V.O., Dzhafarova, O.V., Gudz, T.I., \& Kovalchuk, V.B. (2019), Complementary medicine: International experience of functioning and specific features of the application in Ukraine. Wiadomosci Lekarskie, 72, 1103-1107.

/35/ Wójcik, M. (2019), Local Government Reforms in Poland and European Integration: a report. Warsaw: KSAP.

/36/ Shemshuchenko, Yu.S. (Ed.) (2004), Legal encyclopedia. Kyiv: "Ukrainian Encyclopedia" named after M.P. Bazhana.

/37/ op. sit. in /1/

/38/ op. sit. in /2/

/39/ op. sit. in /6/

/40/ Blanusa, A. (2013), The importance of local governance and citizen participation in modern society. Recent Researches in Applied Economics and Management, 2, 123-128.

/41/ Pal, E. (2018), Models of legal supervision over local self-governments in continental Europe. Pécs Journal of International and European Law, 2, 620.

/42/ op. sit. in /26/

/43/ op. sit. in /6/

/44/ Dashkovska, O.R., Yavor, O.A., Brovchenko, T.I., Huz, Y.V., \& Barabash, O.O. (2021), The features of the implementation of the sports law. Retos, 39, 500504.

/45/ op. sit. in /36/

/46/ Garlicki, L. (2014), Polskie prawo konstytucyjne. Zarys wykładu. Warszawa: LexisNexis.
/47/ op. sit. in /40/

/48/ op. sit. in /41/

149/ Petryshyn, O., \& Petryshyn, O. (2016), International standards of local governance in the context of European integration processes in Ukraine. Bulletin of the National Academy of Legal Sciences of Ukraine, 1, 84-91.

/50/ Aiken, M. (2021), The role of social enterprises in local democratic governance: co-operation or competition? In The Preston Model and Community Wealth Building: Creating a Socio-Economic Democracy for the Future (pp. 172-189). London: Routledg.

/51/ Moskalenko, O.M., \& Boryslavska O.M. (2012), Decentralisation of public authority: the experience of European countries and Ukraine's prospects. Kyiv: Centre for Political and Legal Reforms.

152/ Bordenyuk, V. (2011), Local self-government in district cities with district distribution as a form of decentralization of management of a large city. Bulletin of the National Academy of the Prosecutor's Office of Ukraine, 1, 72- 79.

/53/ Mizsei, K. (2004), Economic Reforms in Ukraine: Time for a New Wave on why poverty remains high in the face of rising GDP and other peculiarities of Ukraine's economic development. Retrieved from: https://zn.ua/author/kalmanmizhey

/54/ Nemec, J., \& Vries M. (2015), Local government structure and capacities in Europe. Public Policy and Administration, 3, 249-267.

/55/ Ukovic, S., \& Hacek, M. (2019), Comparative local governments in Europe. In Contemporary Drivers of Local Development (pp. 75-93). Maribor: Institute for Local Self-Government Maribor.

/56/ Shpotyuk, N. (2015), Theoretical approaches to the organization of municipal governance in the European Union. Public Administration and Local Self-Government, 1, 282-291.

/57/ Duishenalieva, A.D. (2014), Local self-government models: foreign experience. Bulletin of the Bishkek Humanitarian University, 1, 285-287.

/58/ Vystavna, Y., Cherkashyna, M., \& van der Valk, M. R. (2018), Water laws of Georgia, Moldova and Ukraine: Current problems and integration with EU legislation. Water International, 43(3), 424-435.

/59/ Reznik, O., Getmanets, O., Kovalchuk, A., Nastyuk, V., \& Andriichenko, N. (2020), Financial security of the state. Journal of Security and Sustainability Issues, 9(3), 843-852. 